\title{
СУЧАСНІ МЕТОДИ ОЦІНКИ ЕФЕКТИВНОСТІ МЕНЕДЖМЕНТУ ПЕРСОНАЛУ НА ПІДПРИЕМСТВІ
}

\begin{abstract}
Сучасні підприємства вимушені працювати в умовах нестабільності та невизначеності. Це зумовлює необхідність для підприємств безперервно вдосконалюватися, швидко реагувати на зміни та шукати нові шляхи розвитку бізнесу. Одним із ключових факторів забезпечення ефективності управління підприємством стає персонал. Впровадження новітніх методів оиінки ефективності менеджменту персоналу стає надзвичайно важливою проиедурою на підприємстві. У статті проаналізовано теоретичні тлумачення понять «менеджмент персоналу», «ефект» та «ефективність менеджменту персоналу підприємства», щзо дало змогу визначити найважливімі підходи оцінювання організаційної ефективності менеджменту персоналу та їх критерії щзодо оцінювання; визначено основні иілі оиінки ефективності персоналу. При ичьому доиільно розглядати різні види ефективності менеджменту персоналу підприємства, серед яких найбільи поширеними є: економічна, сочіальна, організаційна, иільова. Дослідивщи літературні джерела було описано групи методів, які можна застосувати для оиінки ефективності менеджменту персоналу. Запропоновано поділити методи на 3 групи: якісні методи (характеризують співробітників без застосування строгих кількісних даних), кількісні методи (вважаються найбільш об'єктивними, оскільки всі результати їх проведення виражені в цииррах) та комбіновані методи (використовуються $і$ описові, $i$ кількісні аспекти). Досліджено важливість періодичного оцінювання різних аспектів менеджменту персоналу.
\end{abstract}

Ключові слова: ефект, ефективність менеджменту персоналу, підходи, методи, критерії оцінювання ефективності.

Ю.А. ДЖЕРЕЛЮК

Херсонский национальный технический университет ORCID: 0000-0002-2213-8444

И.С. ЗИНОВЬЕВА

Херсонский национальный технический университет ORCID: 0000-0002-8132-3762

\section{СОВРЕМЕННЫЕ МЕТОДЫ ОЦЕНКИ ЭФФЕКТИВНОСТИ МЕНЕДЖМЕНТА ПЕРСОНАЛА НА ПРЕДПРИЯТИИ}

Современные предприятия вынуждень работать в условиях нестабильности $u$ неопределенности. Это вызывает необходимость для предприятий непрерывно совершенствоваться, быстро реагировать на изменения и искать новые пути развития бизнеса. Одним из ключевых факторов обеспечения эффективности управления предприятием становится персонал. Внедрение новейших методов оценки эффективности менеджмента персонала становится чрезвычайно важной процедурой на предприятии. B статье проанализированы теоретические толкования понятий «менеджмент персонала», «эффект» и «эффективность менеджмента персонала предприятия», что позволило определить важнейшие подходы оценки организационной эффективности менеджмента персонала и их критерии по оценке; определены основные ичели оиенки эффективности персонала. При этом иелесообразно рассматривать различные виды эффективности менеджмента персонала предприятия, среди которых наиболее распространенными являются: экономическая, соииальная, организационная, иелевая эффективность. Исследовав литературные источники были описаны группь методов, которые можно применить для оценки эффективности управления персоналом. Предложено разделить методы на 3 группы: качественные методы (характеризует сотрудников без применения строгих количественных данных), количественные методы (считаются наиболее объективными, поскольку все результаты их проведения выражены в ичиррах) и комбинированные методы (используются и описательные, и количественные аспекты). Исследовано важность периодического оценивания различных аспектов менеджмента персонала.

Ключевые слова: эффект, эффективность менеджмента персонала, подходы, методы, критерии оценки эффективности. 
Y.O. DZHERELIUK

Kherson National Technical University ORCID: 0000-0002-2213-8444

I.S. ZINOVIEVA

Kherson National Technical University ORCID: 0000-0002-8132-3762

\section{MODERN METHODS OF EVALUATION OF PERSONNEL MANAGEMENT EFFICIENCY AT ENTERPRISE}

Modern enterprises are forced to operate in conditions of instability and uncertainty. This makes it necessary for businesses to continuously improve, respond quickly to change and seek new ways to grow their business. One of the key factors in ensuring the effectiveness of enterprise management is staffing. The introduction of the latest methods of assessing the effectiveness of personnel management is becoming an extremely important procedure in the enterprise. The article analyzes theoretical interpretations of the concepts of "personnel management", "effect" and "efficiency of personnel management of the enterprise", which made it possible to determine the most important approaches to assessing the organizational effectiveness of personnel management and their evaluation criteria; the main goals of staff performance evaluation are identified. It is advisable to consider different types of management effectiveness of enterprise personnel, among which the most common are: economic, social, organizational, target. By researching the literature, we have described groups of methods that can be applied to evaluate the effectiveness of personnel management. It is proposed to divide the methods into 3 groups: qualitative methods (characterizing employees without the use of rigorous quantitative data), quantitative methods (considered to be the most objective, since all results of their conduct are expressed in numbers) and combined methods (both descriptive and quantitative aspects are used). The importance of periodic evaluation of various aspects of personnel management is investigated.

Keywords: effect, effectiveness of personnel management, approaches, methods, performance evaluation criteria.

\section{Постановка проблеми}

В сучасних глобальних умовах відбулися великі зміни та поява нових підприємств, яких раніше не було. Серед суб' єктів господарювання за умов кризи виживають ті, що мають високу ефективність та ефект. На межі цього переходу персонал стає все більш важливою складовою успіху підприємств. Необхідно постійно удосконалювати методи роботи, управління персоналом, впроваджувати актуальні моделі кадрових політик сучасності - багатогранних та динамічних. На сьогодні не вироблено єдиного підходу до оцінки ефективності роботи персоналу, тому використовуються різні методики, особливо за умов переходу до постіндустріалізації.

Важливість функції оцінювання ефективності менеджменту персоналу обумовлена декількома аспектами. По-перше, робота 3 оцінки ефективності менеджменту персоналу 3 метою визначення напрямків його розвитку створює передумови для збереження і підвищення конкурентоспроможності підприємства. По-друге, на ринку робочої сили підприємство не завжди може шляхом простого найму задовольнити свої потреби в менеджерах певної кваліфікації, тому дуже важливо правильно оцінити, а потім по можливості перекваліфікувати існуючий управлінський персонал підприємства. По-третє, крім необхідного спеціального навчання, орієнтованого на внутрішньо фірмові запити, підприємства повинні сприяти розвитку у своїх менеджерів творчого мислення і правильного сприйняття ситуації, що виходить за рамки сфери діяльності конкретного працівника на конкретному місці. По-четверте, впровадження нових технологій на підприємствах вимагає істотних інвестицій в оцінку, навчання і розвиток персоналу.

Отже, впровадження новітніх методів об'єктивної оцінки ефективності менеджменту персоналу не просто набуває особливого значення - вона стає надзвичайно важливою процедурою на підприємстві.

Аналіз останніх досліджень і публікацій

Вагомий внесок у вирішення проблеми оцінки ефективності менеджменту персоналу зроблено вітчизняними і зарубіжними науковцями, серед яких: Головатий М.Ф., Балабанова Л.В., Данюка В.М., Дешина С.П., Завіновська Г.Т., Йохна М.А., Лукашевич М.П., Новикова О.С., Приходченко Л., Петенко І.В., Петюха В.М., Рясних Є.Г., Савіна Г.Г., Сокирник І.В., Стадник В.В., Уманець Г.Є., Федулова Л.І., Щербина А.М. та інші. Проте в питаннях підвищення ефективності менеджменту персоналу українських підприємств ще залишається багато проблем, серед яких принципово важливою є недостатня розробленість теоретичних та практичних засад оцінювання ефективності менеджменту персоналу на підприємстві, залишаються недостатньо освітленими питання щодо існуючих підходів та методів оцінки ефективності менеджменту персоналу на підприємстві. 
Формулювання мети дослідження

Метою статті є дослідженні сучасних методів оцінки ефективності менеджменту персоналу на підприємстві.

\section{Викладення основного матеріалу дослідження}

Щоб з’ясувати, наскільки ефективно працює та чи інша система, важливого значення набуває 3'ясування критеріїв оцінювання управління нею. Адже ефективне означає результативне, продуктивне i походить від слова «ефект» (effectus - лат.), тобто дія. Ефектом володіє будь-яка взаємодія, що має якийсь результат, і в цьому сенсі ефект можна розглядати як абсолютну властивість будь-якої взаємодії або процесу, що характеризує їх результат [9].

Менеджмент персоналу - система взаємозалежних організаційно-економічних і соціальних заходів для створення умов щодо нормального функціонування, розвитку й ефективного використання потенціалу робочої сили на рівні організації. Обов'язковою умовою має бути органічне поєднання управління персоналом з концепцією розвитку організації [11].

Сутність понять «ефективність» та «менеджмент персоналу» у їхньому гармонійному та нерозривному зв’язку дозволяє надати наступне визначення ефективності менеджменту персоналу підприємства: ефективність менеджменту персоналу підприємства - це рівень запобігання втрат підприємства обумовлений управлінським впливом на трудову поведінку персоналу підприємства, сформованих за рахунок взаємодії соціальної, організаційної та економічної складових. Таке визначення, на відміну від існуючих, базується на ресурсному та поведінковому підході та надає орієнтири для управлінського аналізу.

Основні підходи до оцінки ефективності менеджменту персоналу та відповідні до них критерії оцінювання представлено на рис. 1. Згідно з першим підходом, об’єктом управління фактично є сукупні ресурси підприємства, тобто ефективність менеджменту персоналу визначається кінцевими економічними результатами діяльності всього підприємства. Згідно з третім підходом, $є$ персонал підприємства, ефективність менеджменту персоналу визначається лише трудовими показниками. Другий підхід на перший план виносить соціальну компоненту. Згідно з четвертим підходом, ефективність менеджменту персоналу визначається рівнем досягнення стратегічних та оперативних цілей.

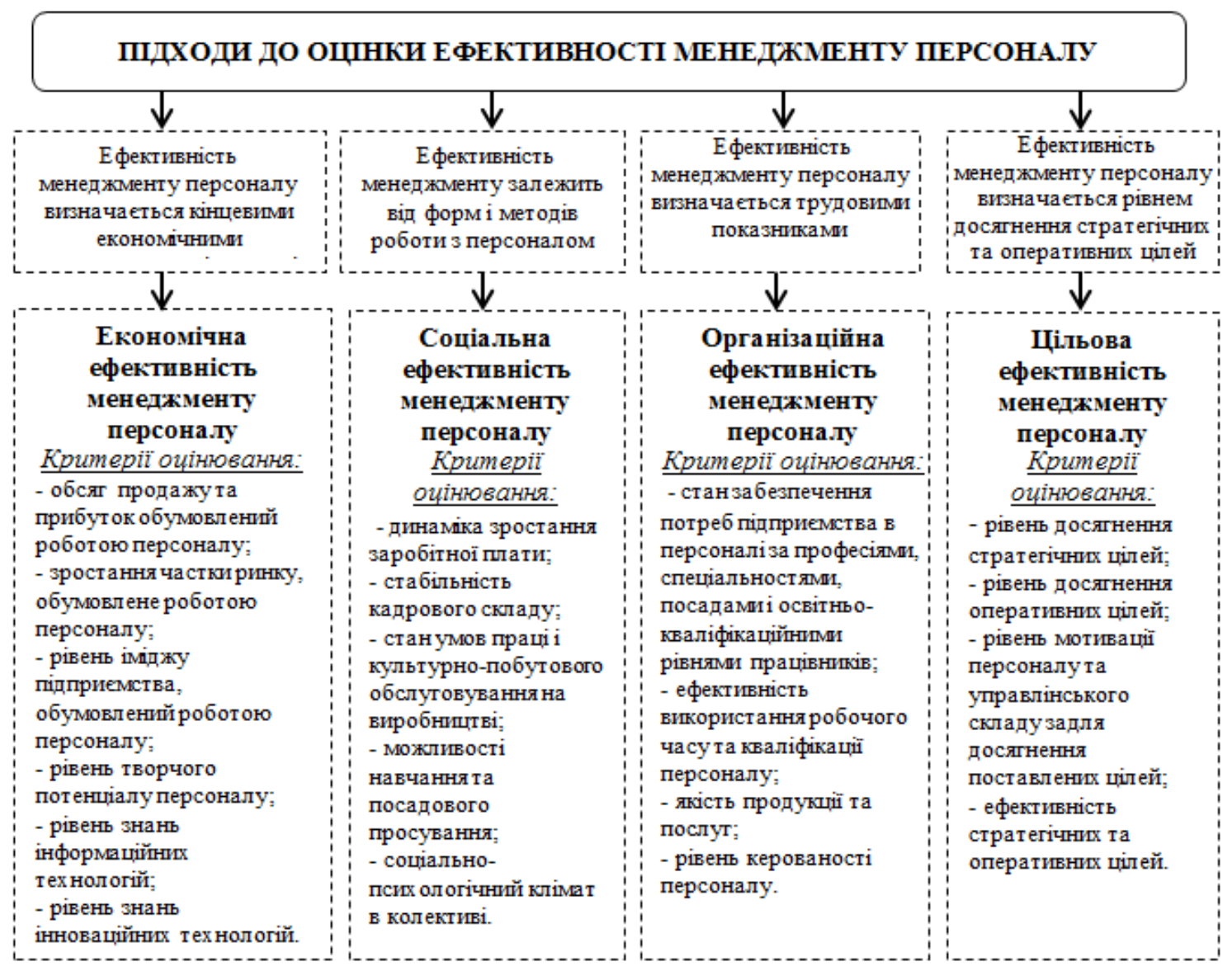

Рис. 1. Підходи до оцінки ефективності менеджменту персоналу та критерії їх оцінювання Джерело: Узагальнено авторами на основі [7; 12] 
Окремо виділяють такі підходи, покладені в основу оцінки ефективності управління персоналом [6]:

- оцінка ефективності управління персоналом, виходячи 3 органічної єдності управління $\mathrm{i}$ виробництва. Недоліком $€$ те, що не визначається внесок управління персоналом в ефективність виробництва;

- акцент на визначенні внеску управління персоналом в ефективність виробництва. Недолік цього підходу полягає у складності оцінки такого внеску через відсутність звітних показників.

Цікавий підхід запропонував такий автор, як Дешина С.П.. В його роботі ефективність управління персоналом пропонується оцінювати за допомогою динамічного нормативу, тобто дається узагальнена оцінка окремих показників економічної ефективності при зіставленні ії з динамікою темпів їх зростання [4].

Оцінка ефективності персоналу принципово відрізняється від оцінки ефективності менеджменту персоналу, оскільки оцінка ефективності персоналу - це формалізований та запланований аналіз трудової діяльності зайнятих, що дає змогу вивчити якісний склад кадрових ресурсів організації, тобто виявити його сильні та слабкі сторони, а оцінка ефективності менеджменту персоналу дозволяє визначати характер управлінського впливу на трудову поведінку та коригувати у відповідності із прийнятими соціальними, економічними, організаційними критеріями.

Оцінка персоналу слугує багатьом цілям. Найпоширенішою є класифікація цілей оцінки, розроблена відомим фахівцем у галузі розвитку людських ресурсів Д. Макгрегором [2]:

- інформативна мета, яка полягає в забезпеченні керівників різних рівнів управління необхідними даними про роботу своїх підлеглих, а також про їх індивідуальні здобутки та недоліки;

- мотиваційна мета, яка передбачає взаємозв'язок матеріальної винагороди і морального заохочення 3 трудовою поведінкою і результатами праці і таким чином орієнтує персонал на покращення діяльності, набугтя нових професійних навичок, необхідних для кращого виконання завдань із соціального захисту;

- адміністративна мета, яка постійно реалізується у процесі прийняття кадрових рішень: підвищення (пониження) по службі, переведення на іншу роботу, перепідготовка та перекваліфікація, заохочення або покарання, припинення трудового договору.

Під час аналізу поточної діяльності береться до уваги те, як підлеглий виконує дану йому роботу. Перспективна діяльність, у свою чергу, потребує оцінки персоналу з точки зору виконання правильних дій для досягнення мети, навчання новому, вимагає оцінки особистих якостей, здібностей та рис, що у подальшому визначає його потенційні можливості. Всі одержані дані $є$ основними при прийнятті правильних кадрових рішень під час організації роботи з людьми. Для того, щоб отримати ці дані потрібно користуватися певними методами. В літературних джерелах ці методи поділені на 3 групи: якісні, кількісні та комбіновані методи. Класифікація основних методів та їх зміст представлено у табл. 1.

Методи оцінки ефективності менеджменту персоналу

\begin{tabular}{|c|c|c|}
\hline № & Назва методу & Зміст \\
\hline 1 & 2 & 3 \\
\hline \multicolumn{3}{|c|}{$\begin{array}{c}\text { Якісні методи (описові): } \\
\text { характеризують співробітників без застосування строгих кількісних даних }\end{array}$} \\
\hline 1 & Матричний метод & $\begin{array}{l}\text { Порівняння якостей конкретної людини } 3 \text { ідеальною } \\
\text { моделлю співробітника для тієї чи іншої посади } \\
\text { управлінського персоналу промислового підприємства. }\end{array}$ \\
\hline 2 & Метод «360 градусів» & $\begin{array}{l}\text { Цей метод має таку назву тому, що працівник оцінюється } 3 \\
\text { усіх можливих сторін. Інформацію про особу одержують } \\
\text { завдяки бесідам із самою людиною, іiі близькими, } \\
\text { колегами, керівниками, підлеглими та навіть клієнтами. }\end{array}$ \\
\hline 3 & $\begin{array}{l}\text { Метод системи довільних } \\
\text { характеристик }\end{array}$ & $\begin{array}{l}\text { Кадрова служба або керівник виділяють найбільші } \\
\text { досягнення і найсерйозніші порушення в роботі і роблять } \\
\text { висновки на основі їх зіставлення. }\end{array}$ \\
\hline 4 & Описовий метод & $\begin{array}{l}\text { Характеризується описом працівника та полягає у } \\
\text { виявленні негативних та позитивних рис особи, яка } \\
\text { атестується. Даний метод не фіксує чіткі результати і тому } \\
\epsilon \text { доповненням до інших методів. }\end{array}$ \\
\hline 5 & Метод комітетів & $\begin{array}{l}\text { Дана оцінка проводиться за участю експертів, які } \\
\text { досліджують працівника } 3 \text { метою виявлення здібностей, } \\
\text { що дають можливість отримати підвищення. Ця } \\
\text { експертиза включає три дії: збір інформації про людину; } \\
\text { вибір якостей, які оцінюються; проведення паралелі між } \\
\text { наявним та необхідним рівнем кваліфікації. }\end{array}$ \\
\hline
\end{tabular}




\begin{tabular}{|c|c|c|}
\hline \multicolumn{3}{|r|}{ Продовження таблиці 1} \\
\hline 1 & 2 & 3 \\
\hline 6 & Метод тестування & $\begin{array}{l}\text { Для оцінки ефективності працівника застосовують } \\
\text { різноманітні тести. Вони поділяються на } 3 \text { групи: } \\
\text { психологічні, кваліфікаційні та фізіологічні. Даний метод } \epsilon \\
\text { дуже ефективним при складанні якісної характеристики } \\
\text { людини, але не враховує як вона себе поводить на } \\
\text { практиці. }\end{array}$ \\
\hline \multicolumn{3}{|c|}{$\begin{array}{c}\text { Кількісні методи: } \\
\text { вважаються найбільш об’єктивними, оскільки всі результати їх проведення виражені в цифрах }\end{array}$} \\
\hline 1 & $\begin{array}{l}\text { Метод алфавітно-числової } \\
\text { оцінки }\end{array}$ & $\begin{array}{l}\text { Основою цього методу є шкала, яка будується відповідно } \\
\text { якісній характеристиці та трудовим досягненням особистості. } \\
\text { Перед початком його використання потрібно визначити, } \\
\text { оцінка яких трудових параметрів потребує дослідження. } \\
\text { Після цього необхідно встановити стандарти цих параметрів } \\
\text { та засоби іх вимірювання. При цьому результати оцінки } \\
\text { значною мірою залежать від ставлення керівника до } \\
\text { підлеглих. }\end{array}$ \\
\hline 2 & Ранговий метод & $\begin{array}{l}\text { Група керівників розробляе щось на кшталт власних } \\
\text { рейтингів співробітників, потім всі рейтинги звіряються між } \\
\text { собою, і тих співробітників, які опинилися на найнижчих } \\
\text { позиціях, звільняють або переводять на менш відповідальну } \\
\text { посаду. }\end{array}$ \\
\hline 3 & Методи бальної оцінки & $\begin{array}{l}\text { За кожне професійне досягнення управлінський персонал } \\
\text { промислового підприємства отримує певну, заздалегідь } \\
\text { обумовлену кількість балів, яку узагальнюють за } \\
\text { підсумками конкретного періоду - місяця, кварталу або } \\
\text { року. }\end{array}$ \\
\hline 4 & $\begin{array}{l}\text { Метод вільної бальної } \\
\text { оцінки }\end{array}$ & $\begin{array}{l}\text { Кожна особистісна якість, властивість співробітника } \\
\text { оцінюється експертами на певну кількість балів, а } \\
\text { результати сумують. На основі } \\
\text { складається рейтинг. }\end{array}$ \\
\hline 5 & $\begin{array}{l}\text { Метод Key Performance } \\
\text { Indicators (KPI) }\end{array}$ & $\begin{array}{l}\text { Система показників, за допомогою якої роботодавці } \\
\text { оцінюють своїх співробітників. Показники кожного } \\
\text { окремого співробітника прив'язують до загальних КРІ } \\
\text { усього підприємства (прибуток, рентабельність). Мета } \\
\text { системи полягає в тому, щоб дії співробітників } 3 \text { різних } \\
\text { служб не були суперечливими і не гальмували роботу } \\
\text { інших підрозділів. }\end{array}$ \\
\hline \multicolumn{3}{|c|}{$\begin{array}{c}\text { Комбіновані методи: } \\
\text { використовуються і описові, і кількісні аспекти }\end{array}$} \\
\hline 1 & Оцінка за результатами & $\begin{array}{l}\text { Даний метод є комунікаційним механізмом, який } \\
\text { допомагає керівнику і підлеглому досягти позитивних } \\
\text { результатів праці та рівня винагород, що задовольняє } \\
\text { обидві сторони. При цьому керівник є консультантом, а не } \\
\text { оцінювачем. Він зосереджує увагу не лише на результатах, } \\
\text { які вже досягнені, але й на підвищенні професіоналізму } \\
\text { працівника. }\end{array}$ \\
\hline 2 & $\begin{array}{l}\text { Метод моделювання } \\
\text { ситуацій }\end{array}$ & $\begin{array}{l}\text { Полягає у створенні штучних обставин та умов праці, які } є \\
\text { близькими до реальних ситуацій. Критерієм оцінки } є \\
\text { здатність пристосування до цих умов, стійкість до стресів } \\
\text { та прийняття відповідних правильних рішень. }\end{array}$ \\
\hline 3 & Система угруповання & $\begin{array}{l}\text { Всіх співробітників управлінського персоналу ділять на } \\
\text { кілька груп - від тих, хто працює незадовільно, до тих, чия } \\
\text { робота практично бездоганна. }\end{array}$ \\
\hline
\end{tabular}




\begin{tabular}{|c|c|c|}
\hline & & Продовження таблиці 1 \\
\hline 1 & 2 & 3 \\
\hline 4 & Метод незалежних суддів & $\begin{array}{l}\text { Для атестації працівника запрошується 5-6 незалежних } \\
\text { членів комісії, які по черзі задають питання атестованому. } \\
\text { Ця процедура є своєрідним допитом, що проводиться у } \\
\text { сфері діяльності особи. Перед комісією розташований } \\
\text { комп’ютер, на якому треба натиснути «+», якщо відповідь } \\
\text { на питання правильна або «-», якщо ні. Після мозкового } \\
\text { штурму комп’ютер аналізує результати і дає висновок. }\end{array}$ \\
\hline 5 & Метод анкетування & $\begin{array}{l}\text { Полягає у тому, що є певна анкета, яка містить риси } \\
\text { характеру працівника. Керівник повинен опрацювати їі та } \\
\text { виставити відмітку напроти тих рис характеру, які властиві } \\
\text { людині, а в іншому випадку - залишити пусте місце. } \\
\text { Кількість всіх позначок є відповідним рейтингом } \\
\text { робітника. }\end{array}$ \\
\hline
\end{tabular}

Джерело: Складено авторами на основі $[1 ; 3 ; 5 ; 8 ; 12]$

За кордоном для оцінки ефективності управління персоналом поширення набули такі методи, як експертна оцінка, метод бенчмаркінгу, оцінка віддачі інвестицій у персонал, методики Д. Філліпса і Д. Ульріха. Оцінка ефективності менеджменту персоналу необхідна, як і оцінка ефективності, результативності та продуктивності стосовно інших сфер управління на підприємстві. Оцінка ефективності менеджменту персоналу - це складне багатоаспектне явище. В загальному розумінні ефективність менеджменту персоналу можна порівнювати з успішністю підприємства. Тобто, ефективність у вигляді кількісних та якісних вимірювачів показує, що управління працівниками здійснюється у правильному напрямі.

Отже, оцінка персоналу - одна 3 найважливіших складових системи управління. В Україні для оцінювання персоналу все ще характерним $є$ не комплексність, брак систематичності та регулярності у застосуванні процедур оцінювання. Періодичне оцінювання дозволяє визначити, чи $є$ цінним даний працівник для підприємства; обгрунтувати доцільність підвищення оплати; оцінити ефективність роботи служби персоналу. Підвищення загальної продуктивності, продуктивності праці, рентабельності, зростання маси прибутку, виконання планів виробництва товарної продукції, збільшення реалізації - усі ці показники відображають загалом високий рівень управління підприємством в цілому і зокрема високий рівень менеджменту персоналу.

\section{Висновки}

Ефективність менеджменту персоналу підприємства - це рівень запобігання втрат підприємства обумовлений управлінським впливом на трудову поведінку персоналу підприємства, сформованих за рахунок взаємодії соціальної, організаційної та економічної складових. Методи оцінки ефективності менеджменту персоналу класифікують на 3 групи: якісні методи (характеризують співробітників без застосування строгих кількісних даних), кількісні методи (вважаються найбільш об'єктивними, оскільки всі результати їх проведення виражені в цифрах) та комбіновані методи (використовуються і описові, i кількісні аспекти). Процес оцінювання ефективності менеджменту персоналу повинен базуватись на принципах дієвості (забезпечувати високий рівень мотивації працівників), практичності (зручність у застосування на практиці як для оцінюючих так і для тих хто оцінюється). Загалом процес оцінювання персоналу повинен сприяти кращому використанню людського потенціалу в системі управління персоналом. На основі проведеного аналізу обгрунтовано необхідність у розробці такого підходу до оцінки ефективності менеджменту персоналу, який би дозволяв зробити оцінку одночасно з точки зору економічної, соціальної, організаційної і цільової ефективності.

\section{Список використаної літератури}

1. Балабанова Л.В. Управління персоналом : навч. посібник / Л. В. Балабанова, О. В. Сардак. - К. : Професіонал, 2006. -512 c.

2. Головатий М.Ф. Управлінські аспекти соціальної роботи: курс лекцій / М.Ф. Головатий (кер. авт. кол.), М.П. Лукашевич, Г.А. Дмитренко та ін. - К. : МАУП, 2004. -368 с.

3. Данюк В.М. Менеджмент персоналу: навч. посіб. / В.М. Данюк, В.М. Петюх, С. О. Цимбалюк та ін.; за заг. ред. В.М. Данюка. - К.: КНЕУ, 2004. - 398 с.

4. Дешина С.П. Оцінка ефективності управління персоналом на основі моделі динамічного нормативу / С.П. Дешина // Питання сучасної науки і практики. - 2009. - № 2(16). - С. 202-205.

5. Завіновська Г. Т. Економіка праці: навч. посіб. / Г.Т. Завіновська. - К.: КНЕУ, 2003. -432 с.

6. Короленко Ю.Е. Удосконалення оцінки ефективності системи управління персоналом / Ю.Е. Короленко // Управління розвитком. - 2010. - № 7(83). - С. 196-197. 
7. Крамеренко А.В. Сучасні підходи до оцінювання ефективності управління персоналом / А. В. Крамаренко // Науковий вісник Херсонського державного університету. - 2014. - №8. - С. 5561.

8. Петенко І.В. Новітній метод оцінювання діяльності персоналу промислового підприємства / I.В. Петренко, Г. Є. Уманець / Проблеми науки. - 2006. - №9. - С. 30-33.

9. Приходченко Л.Л. Ефективність державного управління: критерії і підходи до оцінювання / Л. Л. Приходченко // Теорія та практика державного управління: зб. наук. праць. Харків: Вид-во ХарРІ НАДУ «Магістр». -2006. - Вип. 3 (15). - С. 139-146.

10. Федулова Л.І. Менеджмент організацій: Підручник / Л.І. Федулова, І.В. Сокирник, В.В. Стадник та ін. - К. : Либідь, 2004. - 448 с.

11. Фролова Н.С. Тенденції розвитку трудоресурсного забезпечення Херсонського регіону / Н. Є. Фролова // Соціально-економічний розвиток регіонів в контексті міжнародної інтеграції. 2015. - № 16(5). - T. 1. - С. 36-41.

12. Щербина А.М. Соціальні аспекти забезпечення ефективності менеджменту організації / Г.Г. Савіна, А.М. Щербина, Е. І. Бочкарева // Вісник Хмельницького національного університету. 2014. - №5. - T.2. - C. 180-182.

\section{References}

1. Balabanova L.V. Upravlinnya personalom [Personnel management]. Kyiv, Profesional, 2006, 512 p.

2. Golovatiy M.F. Upravlinski aspekti sotsialnoyi roboti [Management aspects of social work]. Kyiv: MAUP, 2004, 368 p.

3. Danyuk V.M. Menedzhment personalu [Personnel Management]. Kyiv, KNEU, 2004, 398 p.

4. Deshina S.P. Otsinka efektivnosti upravlinnya personalom na osnovi modeli dinamichnogo normativu [Estimation of efficiency of personnel management on the basis of the model of dynamic standard]. Pitannya suchasnoyi nauki i praktiki [Questions of modern science and practice], 2009, Vol. 2(16), pp. 202-205.

5. Zavinovska G.T. Ekonomika pratsi [Labor economics]. Kyiv, KNEU, 2003, 432 p.

6. Korolenko Yu.E. Udoskonalennya otsinki efektivnosti sistemi upravlinnya personalom [Improving the evaluation of the effectiveness of the personnel management system]. Upravlinnya rozvitkom [Development Management], 2010, Vol. 7(83), pp. 196-197.

7. Kramerenko A.V. Suchasni pidhodi do otsinyuvannya efektivnosti upravlinnya personalom [Current approaches to assessing the effectiveness of HRM]. Naukoviy visnik Hersonskogo derzhavnogo universitetu [Scientific Bulletin of Kherson State University], 2014, No.8, pp. 55-61.

8. Petenko I.V., Umanets G.E. Novitniy metod otsinyuvannya diyalnosti personalu promislovogo pidpriemstva [The newest method of evaluating the activity of industrial enterprise personnel]. Problemi nauki [Problems of science], 2006, No. 9, pp. 30-33.

9. Prihodchenko L. Efektivnist derzhavnogo upravlinnya: kriteriyi i pidhodi do otsinyuvannya [Public administration effectiveness: criteria and approaches to assessment]. Teoriya ta praktika derzhavnogo upravlinnya [Public administration theory and practice]. Harkiv, harri NADU «magistr», 2006, Vol. 3 (15), pp. 139-146.

10. Fedulova L.I. Menedzhment organizatsiy [Management of organizations]. Kyiv, Libid, 2004, 448 p.

11. Frolova N. Ye. Tendentsii rozvytku trudoresursnoho zabezpechennia Khersonskoho rehionu [Trends in the development of labor supply in the Kherson region]. Sotsialno-ekonomichnyi rozvytok rehioniv $\mathrm{V}$ konteksti mizhnarodnoi intehratsii [Socio-economic development of regions in the context of international integration], 2015. No. 16(5). Vols. 1, pp. 36-41.

12. Scherbina A.M. Sotsialni aspekti zabezpechennya efektivnosti menedzhmentu organizatsiyi [Social aspects of ensuring the effectiveness of the organization's management]. Visnik Hmelnitskogo natsionalnogo universitetu [Bulletin of Khmelnitsky National University], 2014, No. 5, Vol. 2, pp. 180182. 